\title{
Improving the energy efficiency of buildings based on the use of integrated solar wall panels
}

\author{
Tatyana Schukina ${ }^{1}$, Ilya Kurasov ${ }^{1,}{ }^{*}$, Dmitry Drapaliuk ${ }^{1}$, and Petr Popov ${ }^{1}$ \\ ${ }^{1}$ Voronezh State Technical University, Moscow Avenue, 14, Voronezh, 394026, Russia
}

\begin{abstract}
Frequently used facade glazing makes it possible, on the basis of modern trends in the architecture, to increase the energy efficiency of buildings under construction through the organization of passive solar heat supply. Despite the noted relatively low efficiency of the radiation utilization method recommended for the use, it is possible to increase its indicators by integrating the elements of active solar units in the absorbing layer of the accumulating construction structure. For example, the placement of pipes for the coolant in external enclosing structures will allow year-round exploitation of arrays for passive utilization of solar energy and the use of the obtained heat not only for heating rooms during the cold period of the year, but also for heating water, as well as for absorption chillers in the summer season. The application of the latter contributes to the organization of alternative cooling of the internal blocks of air conditioning systems in the warm period of the year. The listed functions require a different approach in the algorithm of the decisions taken in the design of building structures actively involved in the balance of energy supply. One of the main indicators that determine the possible version of the implementation of the solar radiation utilization system is the achieved temperature potential of the heat flux obtained from the surface of the accumulating layer. The use of the method of sources and the principle of the imposition of fields when solving problems of the depth of embedding and step distance integrated into the surface layer of pipes allows determining the rational range of the values of the specified parameters. This, in turn, is aimed at ensuring the possibility of designing energy-efficient exterior enclosing structures that contribute to the maintenance of the thermal regime required by the multifunctional utilization of solar energy.
\end{abstract}

\section{Introduction}

Ways to reduce resource consumption by buildings of various purposes, which are widely used in the Russian Federation in the construction and subsequent operation, will certainly ensure the reduction of funds sent to pay for utilities [1-2]. In addition, the achieved indicators of the estimated specific energy intensity allow attributing the constructed structures to a high level of classification by energy efficiency [2-4]. However, as subsequent operation shows, theoretically substantiated values of resource consumption

* Corresponding author: ilya.kurasov@yandex.ru 
assessments are often refuted. This provision is caused by contributing changes in the construction of structures, the presence of a significant amount of non-recorded cold bridges, as well as the replacement of automatic valves to manual adjustment devices, the subsequent aging of building materials, insulation disorder and the possible occurrence of other negative factors affecting the operating conditions. But even if to block the effect of these reasons by strict compliance with the technology of building processes and the use of high quality materials and equipment, achieving maximum indicators for the energy efficiency of buildings is possible only in the presence of utilization systems of secondary resources and the use of renewable energy sources $[2,3,5]$.

One of the universally available, environmentally friendly and inexhaustible sources is solar radiation, which, as a rule, is successfully captured, converted and sent to consumers in the southern regions by means of expensive active solar units [5-8]. However, the most economical scheme for the transformation of solar energy into useful heat allows realizing a passive method of utilization [8-10]. It is particularly appropriate for use with architecturally planned facade glazing of buildings, but in this case, the decisions on the arrangement of external fences significantly differ from traditional execution.

In the design of passive solar systems of heat and cold supply of buildings, including enhanced with elements of active solar units, it is necessary to apply another approach to the design of external enclosing structures, in contrast to one corresponding to the regulatory requirements for thermal protection [2-4].

In this regard, the purpose of the studies carried out is the substantiation of the desired execution of integrated solar wall panels, depending on the operating conditions.

\section{Experimental}

An essential feature of the design of the outer walls absorbing radiation is the placement of the carrier heat accumulating layer from the outer side under the translucent fencing (Fig. 1) [9-11]. As such a material, a concrete panel can be used, both precast and monolithic. From the point of view of increasing the regulatory life, the last option is most preferable.

The surface of the accumulating layer, subjected to solar radiation, must be painted in a dark color in order to achieve maximum absorption. In addition, as the studies conducted earlier in the Voronezh State Technical University have shown, the absorption of radiation increases if to form a deeper roughness on the surface, in contrast to the natural, characteristic of these building materials. This can be performed when applying a cementsand solution, followed by alignment of the layer and finishing surface structuring by extruding an array of small shallow holes (Fig. 1, c). The layer of plaster on the surface of the accumulating construction structure may additionally stimulate the effective heat equipment of the captured energy if it contains pipes for the coolant, as well as if partially replace sand with metal bulk material in the technology of preparing the solution. As the latter, waste generated during the processing of metal products can be used. For example, in aircraft construction, during grinding the surface of the supporting structures, duraluminum dust is formed, the addition of which will contribute to an increase in the thermal conductivity coefficient of the plaster layer. This, in turn, will allow both intensive warming of the accumulatory material during the cold period of the year and the coolant in the autumn-spring and summer seasons. 
a.

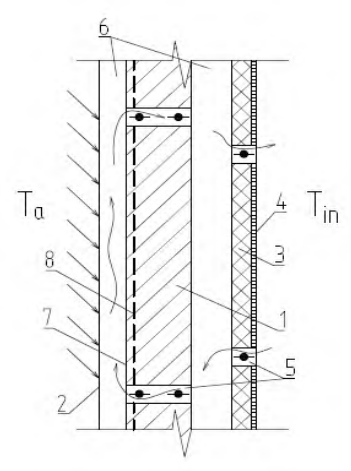

b.

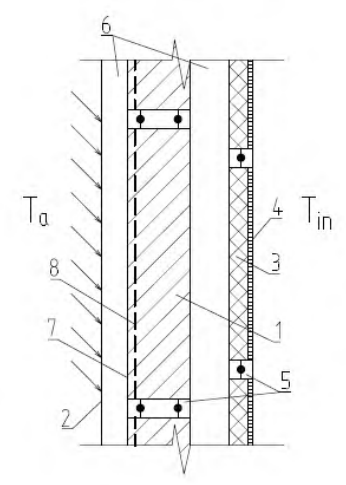

c.

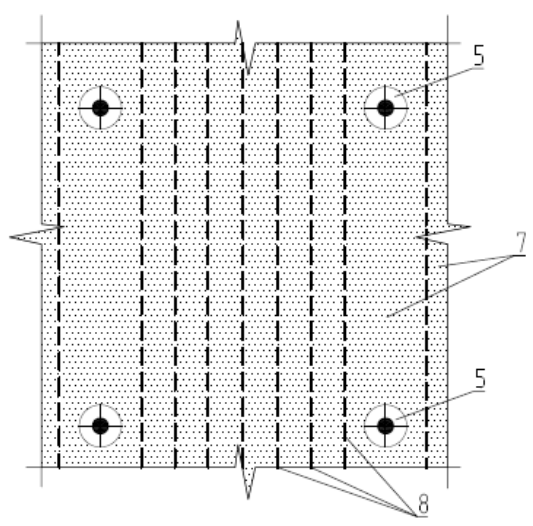

Fig. 1. Scheme of energy-efficient external enclosing structure for passive utilization of solar energy, enhanced with elements of active solar units: a - with intensive irradiation in the cold period of the year; $b$ - at night or under adverse weather conditions in the heating period, as well as in the summer season during the daytime; $\mathrm{c}$ - a fragment of the facade with the placement of pipes for the coolant in the layer of heat-conducting plaster; 1 - heat accumulating layer; 2 - translucent coating; 3 - thermal insulation material; 4 - interior decoration; 5 - air valves; 6 - air layer; 7 - heat-conducting plaster; 8 pipes for the coolant.

Increasing the thermal conductivity of the external layer of the accumulating construction structure is extremely necessary when elements of active solar units are placed in it. In a warm period of the year, the integration of pipes for the coolant into the absorbing surface will allow using caught energy for hot water supply or, at high temperature regime, for the absorption chiller, which converts recycled heat into the cold. 
It should be noted that the second of the designated technical solutions creates favorable conditions for organizing alternative cooling of the internal blocks of microclimate systems. The effectiveness of such a disposal scheme is confirmed by the fact that for air conditioning, the required resources will be covered without increasing the load on the power supply, since it was during the peak consumption hours that the maximum flow of solar energy occurs, which, accordingly, increases the cooling capacity of the absorption units.

To predict an increase in the efficiency of the passive method of utilization of solar radiation in systems with elements of active solar units integrated in external fences, it is necessary to assess the possible change in the thermal conductivity of the absorbing layer. Variating the ratio of the components used in the cement-sandy solution, namely, gradually increasing the content of the added metal inclusions, the heating performance indicators of the absorbing layer can be determined. This, in turn, requires experimental studies of the thermal conductivity of the resulting construction material depending on the composition of the cement-sandy solution used.

The substantiation of the required diameter of the pipes for the coolant, their step-bystep placement, and depth of the location in the heat-conducting layer can be performed by calculations. To do this, use the method of sources when the fixed thermal flow from solar radiation comes, which is characteristic of the time frame of each hour during the daytime [8]. Then the achieved heat power supply with $1 \mathrm{~m}^{2}$ of the battery surface by means of a coolant circulating in the pipes placed in the absorbing layer can be assessed using the source method and the principle of overlaying thermal fields [12]. In this case, the equation for determining the thermal resistance of the pipe in an array containing their limited number will have the form [12]

$$
R=\frac{1}{2 \pi \lambda} \ln \left(\frac{2}{\pi} \cdot \frac{s}{d} \operatorname{sh}\left(2 \pi \frac{h}{s}\right)\right)
$$

where $\lambda$ - thermal conductivity coefficient of the accumulating material, $\mathrm{W} /\left(\mathrm{m} \cdot{ }^{\circ} \mathrm{C}\right) ; s-$ distance between pipes, $\mathrm{m} ; d$ - diameter of pipes, $\mathrm{m} ; h$ - pipe laying depth.

From dependence 1 it follows that the thermal resistance of the pipe in the accumulating layer increases with the depth of its laying and decreases with increasing step. Therefore, to create the conditions of intensive removal of captured heat, the pipes should be located closer to the absorbing surface and with a sufficiently large relative distance from each other.

Thermal pipe resistance calculated in accordance with expression 1 makes it possible to determine its temperature from the equation

$$
q_{F}=\left(t_{F}-t_{T R}\right) \frac{1}{\delta R}
$$

where $q_{F}$ - thermal flow absorbed by $1 \mathrm{~m}^{2}$ of the surface of the accumulating material, $\mathrm{W} / \mathrm{m}^{2} ; t_{F}, t_{T R}$ - temperature of the absorbing surface of the accumulating layer and pipes, respectively, ${ }^{\circ} \mathrm{C} ; \delta$ - thickness of the accumulating layer, $\mathrm{m}$.

The boundary condition determining the thermal flow taking into account two factors the flow of solar radiation through the translucent fencing and cooling of the air layer's interface between the accumulating material of the glazing will be

$$
q_{F}=A_{S} \tau_{v} q_{S}-\alpha\left(t_{F}-t_{0}\right)
$$


where $A_{S}$ - blackness coefficient of the absorption of the irradiated surface; $\tau_{v}$ - light transmission coefficient by external glazing; $q_{S}$ - total solar radiation coming to $1 \mathrm{~m}^{2}$ of the vertical surface, $\mathrm{W} / \mathrm{m}^{2} ; \alpha$ - heat transfer coefficient from the absorbing surface to the air layer, $\mathrm{W} /\left(\mathrm{m}^{2} \cdot{ }^{\circ} \mathrm{C}\right) ; t_{0}-$ air temperature, ${ }^{\circ} \mathrm{C}$;

The total solar radiation coming on $1 \mathrm{~m}^{2}$ of the vertical surface depends on its orientation on the cardinal points and the latitude of the area. In generalized form, the expression to determine its value is as follows

$$
q_{S}=I_{S}^{O R}+I_{D}^{O R}
$$

where $I_{S}^{O R}, I_{D}^{O R}$ - the straight and diffusion solar radiation, respectively, coming on a vertical surface of any orientation in the month under consideration, $\mathrm{W} / \mathrm{m}^{2}$.

To determine the indicators of straight and diffusion solar radiation, it is possible to use the actinometric data or approximating dependencies. For example, the maximum flow of solar energy in July to the vertical surfaces for the northern latitude of the Russian Federation is described with high accuracy by dependencies of the form [13]

$$
\begin{array}{r}
I_{S}^{O R}=a_{0}+a_{1} \varphi+a_{2} \varphi^{2} ; \\
I_{D}^{O R}=b_{0}+b_{1} \varphi+b_{2} \varphi^{2}+b_{3} \varphi^{3},
\end{array}
$$

where $\varphi$ - latitude, ${ }^{\circ}$ n.1..; $a_{0}, a_{1}, a_{2}, b_{0}, b_{1}, b_{2}, b_{3}$ - coefficients of approximation, the values of which are presented in table 1.

Table 1. The coefficients of equations $(5,6)$ for determining the straight and diffusion solar radiation coming on various oriented vertical surfaces with the cloudless sky in July

\begin{tabular}{|c|c|c|c|c|c|c|c|}
\hline \multirow{2}{*}{ Orientation } & \multicolumn{7}{|c|}{ Values of coefficients } \\
\cline { 2 - 8 } & $\mathrm{a}_{0}$ & $\mathrm{a}_{1}$ & $\mathrm{a}_{2}$ & $\mathrm{~b}_{0}$ & $\mathrm{~b}_{1}$ & $\mathrm{~b}_{2}$ & $\mathrm{~b}_{3}$ \\
\hline $\mathrm{S}$ & -358.05 & 16.466 & -0.0272 & -124.27 & 10.91 & -0.1567 & 0.0007 \\
\hline $\mathrm{SE}, \mathrm{SW}$ & 227.23 & 3.3854 & 0.0435 & -571.48 & 40.035 & -0.7207 & 0.0042 \\
\hline $\mathrm{E}, \mathrm{W}$ & 449.21 & 2.2708 & 0.0141 & -542.34 & 41.873 & -0.7817 & 0.0046 \\
\hline $\mathrm{NE}, \mathrm{NW}$ & 722.14 & -13.783 & 0.1615 & 32.104 & 10.301 & -0.2461 & 0.0016 \\
\hline $\mathrm{N}$ & -161.73 & 9.1533 & -0.0606 & 892.08 & -43.298 & 0.7652 & -0.0045 \\
\hline
\end{tabular}

If we additionally take into account the reduction in the intensity of solar radiation due to the indicators of the actual cloudiness, then the sum (4) will include the correction coefficients in accordance with the expression

$$
q_{S}=\left(1-r_{1} l-r_{2}(m-l)\right)\left(I_{S}^{O R}+I_{D}^{O R}\right),
$$

where $r_{1}, r_{2}$ - empirical coefficients characterizing the weakening of the total radiation by the cloudiness of the lower and lower with the average layers, for moderate latitudes $r_{l}=0.65, r_{2}=0.33$ [8]; $l$ - lower cloudiness expressed in the fractions of the unit; $m$ - total cloudiness in the fractions of the unit.

For the task of alternative cold supply, the need for which arises, as a rule, during the period of clear solar radiance, radiation flow should be determined in accordance with (4).

\section{Evaluation}


Let's consider the effect of the parameters of placing pipes for the coolant on the temperature regime arising in the solar wall panel. As an accumulating layer, we will assume a reinforced concrete structure with a thickness of 0.5 and $0.1 \mathrm{~m}$, painted in black from the outside. For enhanced protection against heat loss of the wall panel in the environment, single-chamber double-glazed windows can be used as a fencing, the bandwidth of which for the spectral range should be at least $80 \%[14,15]$.

In the climatic conditions of the Krasnodar Territory, the system of passive solar heat supply, focused on the southern direction, will contribute to the warming of the energy efficiency structure up to $75^{\circ} \mathrm{C}$ and higher. Therefore, a layer of thermal insulation should be provided, effectively preventing the thermal flow into the room. In addition, the pipes for the coolant integrated into the wall panel, along with the removal of useful warmth, will ensure a decrease in heat voltage on the outdoor enclosing structures of the buildings. To increase the degree of radiation capture, it is advisable to paint the absorbing surface in black and to maintain the conditions of natural convection in the air layer in the warm period of the year.

The total flow of solar radiation for Krasnodar in July $\left(45^{\circ} 02^{\prime}\right.$ n.l. $)$ on $1 \mathrm{~m}^{2}$ of the vertical surface oriented to the south is $441 \mathrm{~W} / \mathrm{m}^{2}$ in accordance with dependencies (4-6). Using equation (1) for thermal pipe resistance, its temperature can be determined when substituting conditions (3) in expression (2)

$$
t_{T R}=t_{F}-\delta R\left(A_{S} \tau_{v} q_{S}-\alpha\left(t_{F}-t_{0}\right)\right) .
$$

As the results of the calculations presented in Fig. 2 have shown, with a possible change in the step of the location of the pipes immersed in the accumulation layer near the absorbing surface, the effect of the distance between them on the temperature regime is insignificant. Therefore, the choice of their relative amounts for $1 \mathrm{~m}^{2}$ is determined by the required thermal and hydraulic modes of circulating fluid.

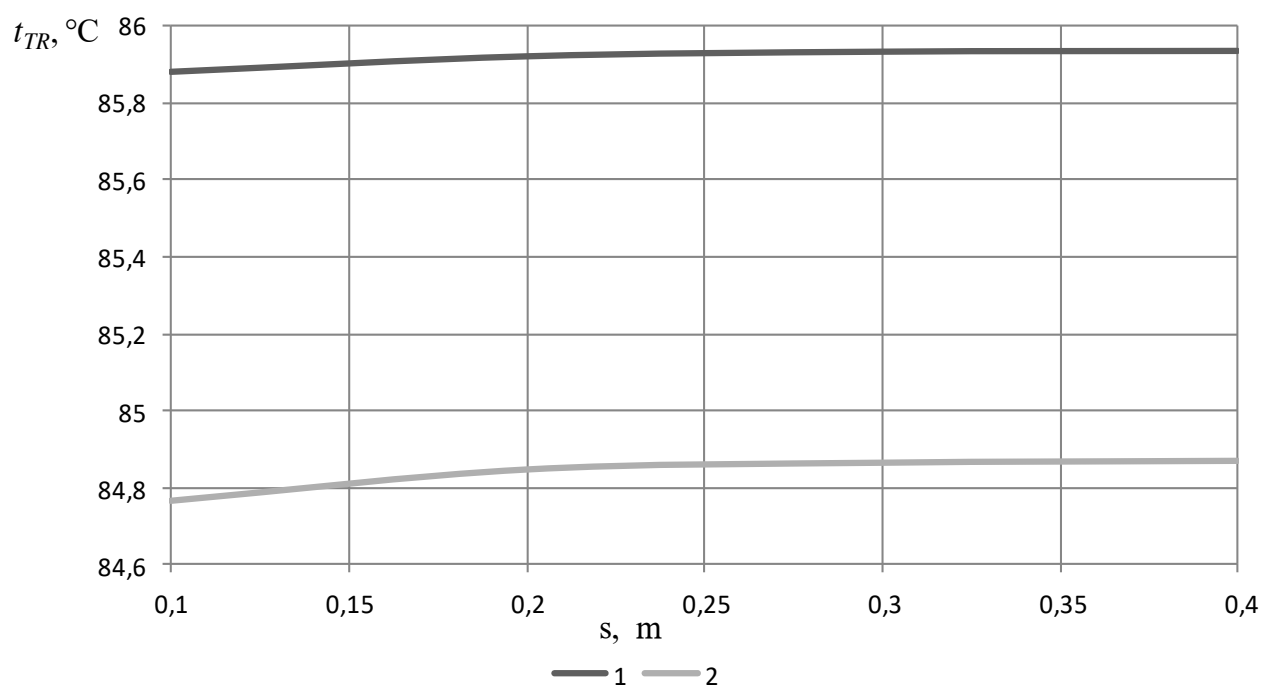

Fig. 2. Pipe temperature at different distances between them: 1, 2 - the thickness of the accumulating array, 0.05 and $0.1 \mathrm{~m}$, respectively.

\section{Conclusions}


1. Taking into account the current trends in the architecture, the most economical way to use such an everywhere available, environmentally friendly, renewable energy source as solar radiation is its passive conversion into useful heat. However, the predominance of clear and hot days in the summer months involves the area of utilized energy, both for hot water supply and for alternative cooling with sufficient resource security. For this, passive systems should be enhanced with elements of active solar units.

2. Placing pipes for circulation of the coolant in the accumulating layer near the absorbing surface allows implementing a multifunctional scheme of solar energy utilization. In these cases, the constructive design of integrated wall panels should ensure a higher potential of the resulting energy. To achieve the specified condition, along with black color, the external absorbing layer should have a deeper roughness, unlike the natural materials used.

3. The location of the pipes for the coolant should be in close proximity to the absorbing surface of the accumulating layer. The distance between pipes for a limited thickness of arrays, characteristic of passive systems, does not significantly affect the thermal regime.

4. Selecting the diameter and the pipe placement step should be made on the basis of the required mode for the circulating coolant.

\section{References}

1. R. M. Aloyan, S. V. Fedosov, L. A. Oparina, Energoeffektivnye zdaniya - sostoyanie, problemy i puti resheniya, 276 (Ivanovo: PresSto, 2016)

2. A. S. SHibeko, M. A. Rutkovskij, Stroitel'naya teplofizika i teplotekhnicheskie izmereniya, 288 (Moscow, Infra-Inzheneriya, 2020)

3. V. T. Tajsaeva, Koncepcii sozdaniya ekoposeleniya $\mathrm{s}$ energosberegayushchimi tekhnologiyami na baze vozobnovlyaemyh istochnikov energii, Malaya energetika, 12, 55-60. (2009)

4. V. A. Butuzov, V. V. Butuzov, E. V. Bryanceva I. S. Gnatyuk, Gelioustanovki v Rossii: analiz rezul'tatov sooruzheniya v 2018-2019 g.g., Santekhnika, Otoplenie, Kondicionirovanie, 2, 89-93 (2020)

5. Z. Mingaleva, N. Vukovic, M. Radovanovic, Solar energy application in houses heating systems in Russia International Journal of Cognitive Research in Science, Engineering and Education (IJCRSEE)., 5(1), 142-148 2017

6. J. A. Duffie, W. A. Beckman, Solar engineering of thermal processes. 2nd Edition, 919 (Wiley Interscience, New York, 1991)

7. V. I. Zemskov, Renewable energy in the agricultural sector, 368 (St. Petersburg: Publishing House "Lan", 2014)

8. A. da Rosa, Renewable energy sources. Physicotechnical basis, 704 (Dolgoprudny: Publishing House "Intellect"; Moscow: Publishing house of MPEI, 2010)

9. V. K. Safronov, Passivnye solnechnye sistemy. Opredelenie i vidy, Innovacii i investicii, 4, 172-174 (2020)

10. I. S. Kurasov, T. V. Shchukina, A. A. Saedi, H. Al, Concerning the issue of alternative cold supply for building climate control systems IOP Conf. Ser.: Mater. Sci. Eng., 962, 032006 (2020)

11. R. A. SHeps, P. A. Golovinskij, T. V. SHCHukina, S. A. YAremenko, Teplovye potoki V passivnoj mnogoslojnoj solnechnoj paneli, Mezhdunarodnyj nauchnyj zhurnal «Al'ternativnaya energetika i ekologiya» (ISJAEE), 7-9, 55-62 (2018) 
12. T. V. SHCHukina, I. I. Polosin, R. A. SHeps, Y. A. I. Karavaeva, Patent 2604119 , MKI F24J 2/24, F24J 2/34, F24J 2/14, F24J 2/16. Solnechnyj teplovoj kollektor, Federal'noe gosudarstvennoe byudzhetnoe obrazovatel'noe uchrezhdenie vysshego professional'nogo obrazovaniya «Voronezhskij gosudarstvennyj arhitekturnostroitel'nyj universitet», №2015106253; 10.09.2016.; Byul., 25, 8 (2016)

13. T. V. SHCHukina, D. M. CHudinov, V. V. SHichkin, I. A. Potekhin, R. A. SHeps, Ocenka prognoziruemogo energozameshcheniya zdanij $\mathrm{s}$ ispol'zovaniem sistemy solnechnogo teplo- i holodosnabzheniya, ZHilishchnoe hozyajstvo i kommunal'naya infrastruktura, 1(4), 54-61 (2018)

14. N. Smith, Thermal performance of secondary glazing as a retrofit alternative for singleglazed windows, Energy and Buildings, 54, 47-51 (2012)

15. E. V. Korkina, Kompleksnoe sravnenie okonnyh blokov po svetotekhnicheskim i teplotekhnicheskim parametram, ZHilishchnoe stroitel'stvo, 6, 60-62 (2015) 